\title{
Czy filozofia polityki przeobrazi się w estetykę polityczną? Przyczynek do analizy metateoretycznej
}

\section{Will Philosophy of Politics Be Transformed into Political Aesthetics? Contribution to the Meta-theoretical Analysis}

\begin{abstract}
Contemporary public debate less and less touches the key issues for the traditional philosophy of politics, and more and more focused on very form of the statements. The political correctness reduces serious, profound discussions and causes, that some philosophical problems are "untouchable". Many issues brought up publicly are starting being subject to an evaluation in aesthetic categories. The aim of the article is to show the contemporary context of designating the external conditions for practicing political philosophy and to present an overview of the factors affecting the framework of content and formal frames such debate.
\end{abstract}

Keywords: philosophy of politics, public debate, aesthetic categories, electronic media

\section{Wstęp}

Współczesna debata publiczna i spory prowadzone w przestrzeni medialnej dotykają w coraz mniejszym stopniu najważniejszych dla tradycyjnej filozofii polityki problemów związanych z funkcjami państwa i rolą poszczególnych instytucji politycznych, uprawnieniami jednostki i zespołem przysługujących jej praw i wolności osobistych itp., a coraz bardziej koncentrują się na samym przebiegu takiej debaty i jej formie. Zjawiska polityczne podlegają w krajach wysoko rozwiniętych mediatyzacji, a część sporów uważa się za tematy tabu (np. dyskusje nad karą śmierci, uprawnieniami imigrantów, kierunkami redystrybucji zasobów). Modna (głównie w krajach anglosaskich) poprawność polityczna wyjaławia język debaty publicznej i czyni niektóre problemy filozoficzne „nie- 
tykalnymi”. Z metafilozoficznego punktu widzenia zespoły dyskutowanych zagadnień powoli przestają przynależeć do tej subdyscypliny filozoficznej, którą określamy mianem „filozofii politycznej”, a w gruncie rzeczy zaczynają podlegać estetyce.

Rola filozofa we współczesnych społeczeństwach zachodnich względem epok dawniejszych do pewnego stopnia ulega przemianie (jest to proces in statu nascendi), w szczególny sposób dotyczy to filozofii praktycznej, w tym filozofii polityki. Dziewiętnastowieczna instytucjonalizacja nauki zawęziła nieco funkcje filozofii teoretycznej, ale również praktycznej. Zwłaszcza na filozofii współczesnej odciska się proces społecznej egalitaryzacji oraz wpływ mediów cyfrowych i upowszechniających się środków komunikacji elektronicznej służących indywidualnemu porozumiewaniu się. Rewolucja telekomunikacyjna z drugiej połowy XX stulecia - jak się zdaje - przyniosła nie mniejsze zmiany mentalne niż rewolucje społeczno-polityczne ery nowożytnej (włącznie z rewolucjami angielską, amerykańską i francuską oraz Wiosną Ludów). Oczywiście nie bez znaczenia pozostaje tu zapoczątkowany na szerszą skalę w XIX w. proces alfabetyzacji i towarzyszący mu wzrost współczynnika scholaryzacji. Jednakże zmiana ilościowa związana z zakresem kontaktów międzyludzkich i szybkością przekazu komunikatów, z którą mamy do czynienia co najmniej od dekady, nie szła $\mathrm{w}$ parze $\mathrm{z}$ ich jakością. Aby dotrzeć do mas, trzeba dostosowywać treść wiadomości do średniej audytoriom, a ta sukcesywnie się zaniża. Z prakseologicznego, a nie tylko psychologicznego punktu widzenia nadawca (w tym przypadku np. filozof społeczny czy polityczny) chcący (skutecznie) przekazywać to, co ma do powiedzenia publicznie szerszemu ogółowi, dostosowuje się do odbiorcy.

Celem niniejszego artykułu jest ukazanie pewnego kontekstu wyznaczającego obecnie niektóre zewnętrze warunki uprawiania tego działu filozofii praktycznej, jakim jest filozofia polityki, a dokładniej omówienie zespołu czynników wpływających na ramy treściowe i formalne debaty publicznej, w której uczestniczą m.in. filozofowie, będąc jej ważnymi elementami podmiotowymi. Należy zaznaczyć, iż zadanie to realizowane jest zaledwie w zarysie. Trendy we współczesnej kulturze, nie tylko zresztą masowej, będące przedmiotem niniejszych rozważań, po pierwsze, trzeba traktować multikauzalnie, po drugie, ujmować jako syndromatyczne epifenomeny, i po trzecie, badać kompleksowo. Omawiany stan rzeczy jest zatem, od strony swej genezy, wieloprzyczynowy, a zjawiska, które obserwujemy w szerzej rozumianej kulturze, bywają pochodną innych współwystępujących z nimi zjawisk zarówno pojawiających się w gospodarce, polityce, jak i nauce oraz w sferze techniki i jej wielorakich zastosowań, i wreszcie, $\mathrm{z}$ racji różnych powiązań i zależności o rozmaitej sile, należy podchodzić do owych współwystępujących fenomenów jako pewnego złożonego systemu wpływającego znów na obieg kulturowy, stan wiedzy obywateli oraz 
nawyki i zwyczaje komunikacyjne dostrzegane w relacjach między „zwykłymi ludźmi”, a także funkcjonariuszami publicznymi rozmaitych szczebli i reprezentujących różne instytucje oraz między „szarymi” obywatelami a politykami i urzędnikami.

Podejmowane tu rozważania obejmują kwestie dotyczące kondycji jednej z subdyscyplin należącej do niemałej rodziny nauk o polityce. Jednak rozpatrywane zagadnienia nie sprowadzają się wyłącznie do opisu istniejących zjawisk i odpowiednich epifenomenów, wyznaczających „zewnętrzne” warunki, w jakich jest uprawiana refleksja z zakresu filozofii polityki, lecz również idą nieco dalej i mieszczą metateoretyczny komentarz do zespołów zastanych różnego typu stanów rzeczy będących przedmiotem zainteresowań, zarówno filozofów polityki, politologów, jak i polityków oraz „Zwykłych” obywateli.

\section{Fakty, powinności, oczekiwania i wartościowania}

Zacznijmy od uwag bardziej generalnych. Rzeczywistość społeczna, we wszystkich jej aspektach, włącznie z politycznym, obejmuje różnego typu obiekty, relacje i własności. W grę wchodzą tu nie tylko jednostki ludzkie i grupy społeczne oraz istniejące instytucje społeczne, w tym panujące obyczaje, ale także różne systemy wartości, normy prawne, poglądy i rozmaite stany mentalne. Świat społeczny - patrząc z perspektywy analitycznej filozofii nauki - obejmuje zatem cztery podstawowe typy stanów rzeczy: stany fizyczne $(S F)$, stany aksjonormatywne $(S A N)$, stany deontologiczne $(S D)$ i stany mentalno-wolicjonalne (SMW). Taki złożony układ zawiera odpowiednio: (a) fakty, czyli fizyczne stany rzeczy; (b) wartości i oceny; (c) powinności, nakazy, zakazy i obowiązki oraz (d) oczekiwania, pragnienia, potrzeby i wyobrażenia.

Wszystkie wspomniane wyżej cztery typy stanów rzeczy i odpowiadające im określone egzemplarze są rzeczywiste (realne) w tym sensie, że są subiektywnie postrzegane jako istniejące obiekty, zbiory, własności czy relacje, choć nie wszystkie te obiekty, zbiory, własności czy relacje okazują się fizycznymi bytami. Wobec tego rzeczywiste stany rzeczy $(S R)$, współtworząc świat społeczny, stanowią pewien zbiór:

$$
S R=(S F, S D, S M W, S A N)
$$

Określone stany rzeczy danego typu pozostają ze sobą w rozmaitych rodzajach związków i wzajemnych zależności (por. np. Brożek, 2012, s. 24-44). Pomiędzy stanami rzeczy danego typu zachodzą różne wielostronne relacje, co zilustrować można schematycznie: 


\begin{tabular}{|c|c|c|}
\hline SF & $\leftarrow$ & $S D$ \\
\hline darzenia & $\leftarrow$ & powinności \\
\hline$\uparrow$ & $\nwarrow$ & $\uparrow \downarrow$ \\
\hline SMW & & \\
\hline pragnienia, oczekiwania \\
potrzeby, wyobrażenia
\end{tabular}

Rysunek 1.

Źródło: opracowanie własne.

Dodajmy, że niektóre stany rzeczy są warunkami (odpowiednio koniecznymi, wystarczającymi bądź sprzyjającymi) występowania innych stanów rzeczy.

Nie jest tak, jak nierzadko potocznie się sadzi, że filozof polityki interesuje się wyłącznie stanami aksjonormatywnymi i deontologicznymi, a politolog, reprezentujący naukę szczegółową, stanami fizycznymi i mentalno-wolicjonalnymi. Wbrew pozorom zasadnicza różnica między filozofem polityki a politologiem nie tkwi w przedmiocie ich zainteresowań i postawie badawczej, lecz w obieranej strategii badawczej i sposobach uzasadniania formułowanych tez. Empiryczne uzasadnienie zajmowanego stanowiska w danej kwestii poznawczej leży przede wszystkim w gestii politologa, filozofowi polityki pozostaje zaś głównie argumentowanie, a argumentacja może - chociaż nie zawsze się to udaje być w danych okolicznościach konkluzywna.

Filozof polityki nie tylko analizuje dane typy stanów rzeczy i (jeśli istnieje taka potrzeba) ich poszczególne egzemplarze, ale także może swym postępowaniem wpłynąć na kształtowanie się stanów rzeczy danego typu oraz oddziaływać - bezpośrednio lub pośrednio - na zachodzące związki między egzemplarzami stanów rzeczy danego typu. Filozofia polityczna jako filozofia praktyczna nie sprowadza się zatem tylko do analiz i porad, lecz również do aktywizacji ludzi w celu realizacji przedsięwzięć określonego rodzaju. 


\section{Filozofia polityczna w działaniu}

Każda epoka historyczna, i ludzie ówcześnie żyjący, miała swe problemy społeczne, polityczne, gospodarcze itp. Refleksja filozoficzna, a zwłaszcza ta z zakresu filozofii praktycznej, częstokroć stanowiła próbę uporania się lub zaradzenia danym problemom. Można powiedzieć w uproszczeniu - parafrazując nieco Marksowską tezę - że (określona) epoka kształtuje (filozoficzną) świadomość. Konkretne koncepcje lub dzieła filozoficzne nierzadko stanowiły bezpośrednią reakcję na pewne zjawiska lub zdarzenia występujące w sferze społeczno-politycznej, ustrojowej bądź społeczno-ekonomicznej. Przykładowo przygotowanie Platońskiego Państwa i Praw było w niemałej mierze reakcją na kryzysy i konflikty polityczne nękające Półwysep Peloponeski, w tym Ateny, w V w. p.n.e. Machiavellowski Książe powstawał jako poradnik wyznaczający reguły „polityki realnej”, a pisany był w dobie rodzenia się idei zjednoczeniowych we wczesnonowożytnych republikach włoskich. Traktat o tolerancji Woltera stanowił próbę zaradzenia przejawom dyskryminacji i prześladowań na tle różnic religijnych ery nowożytnej. Dwa traktaty o rządzie Johna Locke’a i $O$ duchu praw Monteskiusza, wskazujące na zasadność trójpodziału władz, były odpowiedzią na monizm decyzyjny i arbitralność jednoosobowego suwerena w nowożytnych europejskich monarchiach absolutnych. Zmiany struktury społecznej spowodowane konsekwencjami różnych faz rewolucji przemysłowej stanowiły pobudkę dla pisarstwa filozoficznego m.in. utopijnych socjalistów, marksistów, a także choćby Johna Stuarta Milla i jego Poddaństwa kobiet.

Zasygnalizowana wyżej zależność jest - jak wiadomo - również odwrotna: dzieła filozoficzne mogą pośrednio kształtować społeczną rzeczywistość całościowo lub fragmentaryczne, a zatem świadomość filozoficzna ma pewien wpływ na polityczny byt. Powiemy, że mentalno-wolicjonalne i aksjonormatywne stany rzeczy wpływają na fizyczne i inne mentalno-wolicjonalne oraz aksjonormatywne stany rzeczy. Dzieje się tak - przy różnym stopniu recepcji i wierności w interpretacji danych prac filozoficznych - na kilka zasadniczych sposobów: w rezultacie inspiracji, przez społeczną aktywizację i animację określonych grup społecznych i jednostek ludzkich oraz uzasadnianie określonego postępowania lub jakiegoś konkretnego projektu politycznego czy koncepcji ustrojowej. Spektakularną ilustrację stanowi tu działalność amerykańskich ojców założycieli, którzy pisząc Deklarację niepodległości, a potem Konstytucję Stanów Zjednoczonych, żywo interesowali się antyczną i nowożytną myślą republikańską oraz inspirowali pracami Arystotelesa ${ }^{1}$, Polibiusza, Cycerona, Ma-

Stagiryta wprawdzie nie jest reprezentantem myśli republikańskiej w jej ścisłym znaczeniu, ale postulując koncepcję optimum ustrojowego w postaci politei, stworzył podwaliny pod ideę stabilnego systemu politycznego niwelującego potencjalne konflikty społeczne. 
chiavellego i Locke’a, a także Thomasa More’a i Algernona Sidneya. Bywają też przypadki jaskrawego nadużycia i wulgarnego odczytania danych koncepcji filozoficznych, jak w wypadku Nietzscheańskiej koncepcji homo superior i jej karykaturalnej adaptacji na gruncie ideologii nazistowskiej ze wszystkimi tego politycznymi i militarnymi konsekwencjami w postaci podbojów i popełnionych zbrodni wojennych.

Filozof polityki, stając w danych warunkach systemowych (obejmujących m.in. reżim polityczny, strukturę społeczną, system społeczno-gospodarczy itp.) przed wyborem skali ewentualnego zaangażowania w sprawy publiczne, może brać pod uwagę trzy zasadnicze typy postaw wobec aktualnych problemów życia politycznego i społecznego: bierną, aktywną i reaktywną. Myśliciel może zatem poprzestać na pisaniu fachowych tekstów, nie angażując się otwarcie w sprawy publiczne, może reagować na zastaną sytuację niejako post factum i może starać się ją aktywnie kreować za pośrednictwem wypowiedzi ustnych bądź pisemnych. Skuteczność takich wypowiedzi i zasięg odziaływania zawsze zależały od medium, jakim się dany myśliciel posługiwał, stopnia przygotowania audytorium oraz wzmiankowanych uwarunkowań systemowych.

\section{Hiperprzyspieszenie historyczne i trendy kulturowe}

Rozwój naukowo-techniczny epoki późnonowożytnej i związana z nim rewolucja przemysłowa przełomu XVIII i XIX w. spowodowały istotne zmiany w obrębie struktur społecznych, postaw, zwyczajów i świadomości szerokich rzesz ludzkich. Od drugiej połowy XX stulecia w coraz krótszych interwałach czasowych dochodzi do głębokich zarówno strukturalnych, jak i funkcjonalnych zmian niektórych fragmentów świata społecznego. Czas uległ swoistemu skurczeniu, a zachodzące przekształcenia - przyspieszeniu.

\subsection{Między poprawnością polityczną a werbalno-ikoniczną agresja}

Rewolucja telekomunikacyjna $\mathrm{z}$ przełomu lat 70. i 80. XX w. przekształciła ilościowo i jakościowo metody wymiany informacji. Wypowiedzi publiczne, w szczególności od momentu dominacji w komunikacji masowej mediów elektronicznych, spadku czytelnictwa prasy drukowanej i nastania rewolucji Web 2.0., uległy zmianie jakościowej. Z jednej strony mamy do czynienia z rozmaitymi formami społecznej (obyczajowej) kontroli owych wypowiedzi, z drugiej natomiast z pozbawioną zahamowania swobodą ostentacyjnego wyrażania ocen i opinii (najczęściej uzewnętrznianych w sposób anonimowy w internecie). 
Pierwsze ze wspomnianych zjawisk uosabia zapoczątkowana $\mathrm{w}$ krajach anglosaskich tzw. poprawność polityczna, emanacją drugich są zaś ataki słowne i wizualne spotykane w szerzej ujmowanej przestrzeni publicznej.

Poprawność polityczna (powstająca w warunkach emancypacji rozmaitych grup wcześniej nieuprzywilejowanych) stała się w krajach zachodnich jednym z głównych mechanizmów moderujących i katalizujących rozmaite wypowiedzi publiczne, a do pewnego stopnia również prywatne ${ }^{2}$. Owa poprawność - rozumiana jako określony typ postawy i zarazem rodzaj zachowania - wyznacza treściowe i formalne ramy części kontaktów międzyludzkich oraz w pewnej mierze masowej komunikacji. Tak więc sposób prowadzenia otwartych dyskusji został podporządkowany danym nieskodyfikowanym regułom selektywnej wymiany myśli. Używane słowa i określone związki wyrazowe (czasami wybrana terminologia), a także pewne symbole i gesty poddane zostały oczekiwanemu społecznie, a przynajmniej przez niektóre grupy osób, osobliwemu ocenzurowaniu. Pojawiły się zatem takie tematy, których nie należy, nie można lub nie wypada poruszać publicznie, jak np. wysoka przestępczość wśród określonych grup etnicznych zamieszkujących określone kraje, radykalizm postaw członków danych grup religijnych, zaangażowanie niektórych ludzi w zbrodnie wojenne dokonywane na członkach ich zbiorowości itp. Przekroczenie lub złamanie takich nieformalnych zakazów uznawane bywa w niektórych krajach za niedopuszczalny publicznie sposób formułowania i wyrażania myśli.

Jednym z przejawów agresji słownej lub dezawuowania werbalnego adwersarzy, konkurentów czy wrogów (faktycznych bądź wyimaginowanych) jest perswazyjne (często przy tym moralizatorskie i mocno światopoglądowo nacechowane) etykietkowanie. Na przykład ludzie zaangażowani w jakiś konflikt zbrojny, a niebędący członkami regularnej armii, jeśli są „nasi”, bywają określani zwykle mianem „partyzantów” lub „bojowników”, gdy są „obcy” nazywa się ich np. „terrorystami”. To rzecz nienowa, ale w erze dominacji mediów elektronicznych i szybkości przebiegu procesów komunikacyjnych kategoryzowanie przebiega niezwykle łatwo. Podobnie jest $\mathrm{z}$ rozpowszechnionymi epitetami, takimi jak np. „lewak” czy „faszysta”.

W czasach nowożytnych wymiana informacji i poglądów odbywała się na ogół w miejscach publicznych, takich jak np. kawiarnie, a w wypadku wyższych sfer w arystokratycznych salonach. Bliskość i bezpośredniość kontaktów w takich oko-

Jak należałoby sądzić, istotny wpływ na pojawienie się poprawności politycznej miały przeszłość kolonialna niektórych państw będących dawnymi metropoliami i łączone z nią formy społeczno-ekonomicznego wyzysku oraz imperialnej dominacji, poczucie winy z powodów dyskryminacji rasowej, a także poczucie bezpośredniej lub pośredniej odpowiedzialności obywateli niektórych krajów za masowe zbrodnie wojenne (w tym ludobójstwo) z okresu drugiej wojny światowej (por. np. Hughes, 2011; Charlton, 2011). 
licznościach ograniczała skalę i zakres słownej agresji. Zjawiska językowe polegające na nacechowanym - zwykle pejoratywnie bądź prześmiewczo - opisywaniu bądź ocenianiu poszczególnych ludzi czy jakichś grup społecznych upowszechniają się zwykle tam, gdzie brak zakazów, kontroli lub wzorców osobowych właściwych postaw, ale również dobrej woli osób wypowiadających się w danej sprawie.

\subsection{Estetyzacja i deestetyzacja treści i formy przekazu publicznego}

W sztuce współczesnej z jednej strony i we wzornictwie przemysłowym oraz usługodawstwie z drugiej można dostrzec pewną prawidłowość polegającą na tym, że dzieła mające uchodzić za przynależące np. do kultury wysokiej nierzadko emanują brzydotą, szokują, porażają formą, natomiast przedmioty codziennego użytku oraz usługi, a także ich reklamy są projektowane i przygotowywane z myślą o zaspokajaniu potrzeby estetycznej obcowania z obiektami uważanymi za ładne, wygodne, poruszające itp. Fenomen ten sprowadza się do deestetyzacji sztuki i estetyzacji życia codziennego - w ujęciu klasycznych kategorii z zakresu filozofii sztuki (Dziemidok, 2002, s. 301-311).

W pewnej mierze zjawisko to obejmuje też media dzisiejsze i sferę publiczną. Podstawowe kategorie estetyczne, takie jak piękno, brzydota czy wzniosłość, stają się kategoriami opisowymi życia publicznego i odnoszą się również do przekazu w mediach współczesnych. W odniesieniu do życia publicznego mamy zatem estetyzację komunikatów (co szczególnie wyraźnie widać na przykładzie kształtowania wizerunków polityków i reklamy politycznej) oraz deestetyzację przekazu medialnego: szokowanie i epatowanie przemocą, poruszanie widza (resp. słuchacza), koncentrowanie się na „aferze dnia” itp. (vide programy informacyjne i pierwsze strony tabloidów). Znaczący rozdźwięk w estetyce przekazu pojawia się (zwykle w treści, rzadziej w formie) między profilowanymi kanałami tematycznymi poświęconymi np. modzie, motoryzacji, stylowi życia czy odżywiania się a kanałami i programami informacyjnymi. Od kiedy idee włącznie z programami politycznymi uczyniono towarem, estetyzacja tego, jak i o czym się publicznie mówi, stała się właściwie nieuchronna.

\subsection{Polityzacja mediów i mediatyzacja polityki}

Upowszechnienie się łączy satelitarnych, telefonii komórkowej, telewizji kablowej, komputerów osobistych i dostęp do szerokopasmowego internetu odcisnęły się na związkach i wzajemnej presji oraz zależności między ludźmi mediów a politykami i vice versa, a także między politykami, zwykłymi obywatelami, właś- 
cicielami i zarządcami środków masowego przekazu a osobami pracującymi w mediach (począwszy od dyrektorów programowych, redaktorów prowadzących i prezenterów, reporterów, po dźwiękowców oraz realizatorów obrazu itd.).

Zaangażowanie ideologiczne i polityczne ludzi mediów oraz udział polityków w walce o władzę za pośrednictwem rozwiniętych kampanii medialnych (nie tylko w czasie wyborów) i przy użyciu mediów stały się signum temporis ery globalizacji. Selekcja informacji, odzwierciedlająca się w tzw. agenda setting, obejmuje nie tylko to, co zostaje zaprezentowane w odpowiedniej kolejności, lecz także i to, co zostaje zmarginalizowane lub ostatecznie pominięte w przekazie. W rezultacie odbiorca może być niedoinformowany, a debatowane kwestie ukazane ze zubożoną argumentacją spierających się stron.

Podane wyłącznie zasadom rynkowym i pełnej komercjalizacji media zaniżają poziom nadawanych programów: ilość nieuchronnie wypiera jakość. Działanie w kategoriach czysto marketingowych i prezentyzm (scil. skupianie się wyłącznie na bieżących sprawach) ogranicza myślenie prospektywne i planowanie długookresowe. Dotyczy to zarówno ludzi mediów, jak i polityków. Jednym z niebezpieczeństw, które niesie dla porządku demokratycznego telewizja (a w czasach nam najbliższych również internet), jest kreowanie uproszczonego i niekiedy bardzo zdeformowanego obrazu świata (dotyczy to zarówno faktów, jak i hierarchii wartości), w tym także nadreprezentacja przemocy w relacjach międzyludzkich i epatowanie wszelakiego rodzaju sensacją (Popper, Condry, 1996). Afera dnia lub „szokujące” wydarzenie dnia usuwa z pola widzenia przeciętnych odbiorców istotne, lecz mało spektakularne informacje. Upraszczaniu widzenia świata społecznego sprzyja dostrzegana w wielu społeczeństwach zachodnich silna polaryzacja stanowisk światopoglądowych polityków i „Zwykłych” obywateli (por. np. Zaller, 1992; Fiorina, Abrams, Pope, 2005; Abramowitz, 2010).

Notabene odpowiedzialność mediów informacyjnych związana z rzetelnością przekazywanych komunikatów jest gwarantem trwałości demokracji. Gdyż nie tylko wolność słowa, ale i dostęp do obiektywnych i sprawdzonych informacji są prawem obywateli społeczeństw otwartych jako takich oraz cechami instytucjonalnymi współczesnych demokracji liberalnych, tj. poliarchii w sensie dahlowskim (Dahl, 1971). Skądinąd prawo dostępu do rzetelnej informacji oraz ochrona obywateli przed dyktaturą i rozmaitymi formami tyranizowania tychże obywateli dzięki kontroli i krytyce polityków i urzędników są uważane za fundament nie tylko demokratycznego, lecz także praworządnego ładu społecznego ${ }^{3}$.

Nieprzypadkowo w klasycznej literaturze liberalnej (stanowiącej w pewnej mierze odnośnik dla nowożytnego i współczesnego konstytucjonalizmu oraz teorii demokracji przedstawicielskiej) prawo do publicznego wygłaszania opinii i ocen oraz krytyka rządzących uchodziły za rękojmię wolności jednostek i za zaporę przeciwko nastaniu władzy absolutnej (por. np. Locke, 1992, passim; Mill, 1959, s. 122-123, 142-145, 191-192; von Hayek, 2012, s. 118-119). 


\subsection{Między informacją, komentarzem, słowem a obrazem}

Zaangażowanie polityczne i światopoglądowe ludzi mediów powoduje to, że nawet $\mathrm{w}$ prasie opiniotwórczej zdarza się pomieszanie informacji z komentarzem. Co więcej, media współczesne (zwłaszcza elektroniczne) dokonują swoistego metaopisu w postaci rozmaitych auto- i metakomentarzy, niejednokrotnie mocno nacechowanych światopoglądowo. Owe środki masowego przekazu do pewnego stopnia zajmują się same sobą; nierzadko zamiast przedstawiać bądź komentować to, co dzieje się w rzeczywistym świecie, dziennikarze i publicyści nadmiernie koncentrują się na tym, co dotyczy opisu świata pozajęzykowego, i na komentarzach do faktycznych zdarzeń czy postaw rozmaitych ludzi.

Współczesny przekaz medialny - w szczególności skierowany do odbiorcy masowego - wyróżnia swoista periodyczna monotematyczność (chodzi o intensywną eksploatację wybranego tematu (resp. problemu) w danym czasie z pominięciem innych ważkich kwestii, uznawanych w określonym momencie za mniej „medialne”). W rezultacie jesteśmy świadkami zaburzenia proporcji treści w prowadzonym procesie komunikacji. Dywersyfikacja przekazu publicznego (identyfikowana $\mathrm{z}$ istnieniem tzw. mediów niezależnych i amatorskich stacji nadawczych, w tym rozmaitych portali internetowych) przyniosła różnorodność formy i treści komunikatów, ale częstokroć pociągała za sobą znaczne obniżenie ich jakości. Nadmierna popularyzacja czy też skrajna egalitaryzacja, rozumiana jako obniżanie poziomu do „wspólnego mianownika”, czyli ogólnego poziomu intelektualnego odbiorców, wiąże się - często z konieczności zagwarantowania efektywności porozumiewania się - z symplifikacją, schematycznością oraz brakiem weryfikacji komunikatów.

Na oficjalny obieg informacji nakłada się „oddolna” wymiana komunikatów. Inkluzja społeczna i egalitaryzm w połączniu z upowszechnieniem się nowinek technologicznych przyniosły osobliwy bunt samodzielnych nadawców masowych w mediach elektronicznych (por. np. Ortega y Gasset, 1982, rozdz. 1-2; Keen, 2007). Skutkiem tego jest dywersyfikacja źródeł informacji, ale wespół $\mathrm{z}$ ich zazwyczaj niewielką rzetelnością i wiarygodnością.

Słowo pisane ustępuje obrazowi. Ma to swe wyraźne odzwierciedlenie m.in. $\mathrm{w}$ stosowanych formach przekazu masowego. Współczesna kultura w dużej mierze stała się obrazkowa. Niektórzy badacze zwracają uwagę na pojawienie się nowego fenomenu polegającego na kształtowaniu się we współczesnych czasach swoistej kultury neomediewalnej. Analogia do średniowiecza polegać ma tutaj m.in. na rosnącej roli ikonografii (scil. sztuki obrazkowej) w procesie komunikacji, współwystępowaniu w formie amalgamatu sztuki wysokiej i popularnej, nastaniu czasów indywidualnej niepewności i nowego nomadyzmu, a w wymiarze geopolitycznym na powstawaniu (potencjalnie) względnie jednolitego, 
ponadnarodowego bytu (vide Wspólnoty Europejskie) o nowym rodzaju wewnętrznej i zewnętrznej suwerenności (por. Eco, 1999, s. 77-101; Bull, 1985, s. 254-255).

\section{Debata publiczna i odpowiedzialność obywatelska}

W czasach późnej nowożytności i jeszcze do połowy XX w. politycy mieli w zwyczaju pisanie książek (nie tylko pamiętników i wspomnień), dziś, jeśli coś większego $\mathrm{w}$ formie pisemnej powstaje, to zazwyczaj przy walnym udziale ghostwriterów; bieżąca pisemna komunikacja sprowadza się zazwyczaj do wymiany jednozdaniowych komunikatów, np. w postaci tweetów na znanym portalu społecznościowym. Współcześni politycy (w swojej masie) przestali być partnerami do rozmów na tematy z zakresu filozofii politycznej, istotną pracę myślową wykonują za nich w tym zakresie grupy robocze składające się na ogół z profesjonalistów. (Dotyczy to głównie sytuacji związanych z prowadzeniem sporów światopoglądowych, a obejmujących kwestie prawno-ustrojowe). Z drugiej strony osłabienie roli autorytetów i wzrost znaczenia wiedzy eksperckiej oraz rozmaitego rodzaju wyspecjalizowanego poradnictwa (por. np. Giddens, 2001, rozdz. 4), z czym mamy do czynienia od ostatnich dwóch dekad XX stulecia, idą $\mathrm{w}$ parze $\mathrm{z}$ częściową zmianą funkcji samej debaty publicznej. Otóż debata ta - rozumiana i jako pewnego rodzaju wydarzenie komunikacyjne i jako proces wymiany informacji - przestała być li tylko narzędziem rozwiazywania danych kryzysów i konfliktów społecznych czy też formą konstruktywnej wymiany opinii, ale stała się również instrumentem indywidualnej ekspresji i epatowania odbiorców własnymi partykularnymi problemami i ideologicznymi zapatrywania$\mathrm{mi}$, dotyczy to zwłaszcza internetowej przestrzeni medialnej (por. np. Habermas, 2007; Kampka, 2014; Toeplitz, 2006; Evans, 2016).

Filozof polityki może się nie angażować $\mathrm{w}$ debatę publiczną i milczeć $\mathrm{w}$ danych sprawach lub przemilczeć pewne kwestie, ale może też starać się oddziaływać na decydentów jako członków egzekutywy, instytucje i normy prawne via członkowie legislatywy oraz na postawy obywateli. Przedsięwzięcia takowe mają rozmaite skutki (czasem nieprzewidywalne) i to zarówno wtedy, gdy nie robi się nic, jak i wówczas, gdy jednak podejmuje się próby wpływania na wzmiankowane wyżej podmioty. Odpowiedzialność jednak (i ta prawna, i moralna) obejmuje nie tylko konkretne czyny, ale także bezczynność.

Przyczyną milczenia, będącego w istocie brakiem mowy zewnętrznej (Dąmbska, 1975, s. 93), może być zarówno obojętność, jak i niewiedza. Niemówienie czegoś lub o czymś jest swego rodzaju formą przyzwolenia na dane działania określonych ludzi czy zjawiska (pomijamy milczenie, czyli niemówienie wyni- 
kające z jakiegoś stanu chorobowego). Brak reakcji na ludzką krzywdę, publicznie wygłaszane fałsze, pomówienia czy też agresję fizyczną okazuje się przejawem milczenia w ujęciu negatywnym. Milczenie może pełnić kilka rozmaitych funkcji (por. Dąmbska, 1975, s. 93-105). Milczenie może być zatem traktowane i jako środek taktyczny w komunikacji, i jako pewna kategoria etyczna. Może być ono niezbędnym warunkiem skutecznego działania w fazie planowania i wykonywania danej czynności. Milczenie bywa, w określonych okolicznościach, obowiązkiem (np. gdy trzeba dochować tajemnicy), cnotą, gdy nie jest obowiązkiem, lecz służy jakiemuś dobru moralnemu, a pozostaje cnotą heroiczną, bowiem naraża milczącego na cierpienia, których nie milcząc, mógłby uniknąć, wreszcie okazuje się występkiem lub winą, gdy mówienie było obowiązkiem (społecznym nakazem), a dana osoba głosu nie zabrała. Jak w takich okolicznościach, w dyskusji np. o stanie państwa, prawach obywatelskich, skrajnych nierównościach społeczno-ekonomicznych itp., ma się zachować filozof polityki? Jak należałoby kategoryzować jego działania? Pytania te pozostają otwarte, ale aby wyrazić swe stanowisko w danej kwestii, trzeba się wypowiedzieć w formie ustnej lub pisemnej.

Gdy istnieje rzeczywista swoboda otwartego wypowiadania się na tematy dotyczące życia publicznego, choćby w obszarach odpowiadających zainteresowaniom filozofów polityki, wówczas mamy do czynienia $z$ emanacją realizacji idei wolności słowa, możność śledzenia i niezależnego odbioru takich wypowiedzi są jednym $\mathrm{z}$ wyrazów ziszczenia się prawa dostępu do informacji, natomiast prowadzona debata nad poruszanymi kwestiami to $\mathrm{w}$ istocie jedna $\mathrm{z}$ form kontroli społecznej prowadzonej nad podmiotami polityki i instytucjami politycznymi. Jak wiemy, filozof polityki, czynnie angażując się w życie publiczne i występując $\mathrm{w}$ danym sporze politycznym, może nie tylko przekonywać na rzecz swych racji, ale także swych odbiorców ostrzegać, napominać, uświadamiać, jak i motywować oraz zachęcać do jakichś działań. Nie zapominajmy, że każda debata publiczna prowadzona jest w danym kontekście społeczno-kulturowym, który nierzadko znacząco ogranicza jej formy i treść. Współczesna „dywersyfikacja" źródeł informacji, autonomia niezależnych nadawców i popularność portali społecznościowych (głównie w krajach zachodnich) powoduje dodatkowo, że możliwości oddziaływania potencjalnie się zwiększają, lecz faktycznie są ograniczone, gdyż profesjonalny filozof (przynajmniej w odbiorze społecznym) ma formalnie, choć nie pod względem merytorycznym, równoprawnych konkurentów w postaci politycznych myślicieli-amatorów.

Preferencje światopoglądowe, w tym akceptowane wartości, indywidualne zainteresowania i predyspozycje intelektualne szerokich rzesz uczestników życia publicznego jako odbiorców danego typu komunikatów, powodują, co już zasygnalizowano, że masowość procesu komunikacji staje niejednokrotnie w kolizji $\mathrm{z}$ wagą poruszanych $\mathrm{w}$ debatach publicznych wątków problemowych i jakością 
prowadzonych wnioskowań, choć niekoniecznie - z prakseologicznego punktu widzenia - z nieskutecznością dotyczącą oddziaływania na audytorium, częściej raczej z przeciwskutecznością wzmiankowanych poczynań.

Novum w dziejach powszechnych są protesty społeczne, wystąpienia i manifestacje organizowane na ulicach miast $\mathrm{w}$ pewien sposób zintegrowane $\mathrm{z}$ systemem masowego komunikowania (głównie via telefonia komórkowa i portale społecznościowe) jako swoista alternatywa dla oddziaływania piórem przez intelektualistów na decydentów. Publiczna wymiana opinii i ocen jest tu jednak uproszczona do postaci krótkich haseł i kilkuzdaniowych sloganów. Nie zmienia to jednak faktu, że tego typu działania niejednokrotnie bywają o wiele skuteczniejsze pod względem społecznego wpływu od najbardziej wyszukanych argumentacji filozoficznych, zwłaszcza wtedy, gdy wydarzenia takie zostają nagłośnione w przestrzeni medialnej i wielokrotnie przywoływane w rozmaitych programach informacyjnych.

\section{Uwagi końcowe}

Akademicka filozofia polityki uprawiana w sposób tradycyjny - jako pewien typ wysublimowanej refleksji dyskursywnej skierowanej do grupy profesjonalnych odbiorców, którzy swymi poglądami wymieniają się na kartach specjalistycznych monografii i w artykułach publikowanych w fachowych periodykach bądź też dzięki cyklom wykładów uniwersyteckich - zapewne, w dającej się przewidzieć przyszłości, przetrwa i pozostanie bez większych zmian w dotychczasowej postaci. Postawione swego czasu przez Karola Marksa pytanie - być może nawet prowokacyjnie - o to, czy z punktu widzenia celowości zasadniczej aktywności filozofa świat należy poznawać, czy też go zmieniać, jest w gruncie rzeczy zagadnieniem pozornym dla myśliciela będącego odpowiedzialnym i zaangażowanym w sprawy społeczne obywatelem w reżimie demokratycznym. Metafilozoficzny dylemat związany z określeniem własnej funkcji miałyby polegać tutaj na tym, czy dany filozof polityki powinien pozostawać biernym analitykiem rzeczywistości społeczno-politycznej piszącym wyłącznie dla profesjonalistów, czy też zostać zaangażowanym jej kreatorem. Jeśli jednak filozofowie polityki zajmowanym stanowiskiem $\mathrm{w}$ danej kwestii pragnęliby podzielić się z szeroką rzeszą odbiorców, niekoniecznie w pełni przygotowanych merytorycznie, to muszą się liczyć z potrzebą wprowadzania symplifikacji zarówno w formie, jak i treści komunikatów. Takie zabiegi dostosowawcze są swoistego rodzaju „kompromisem komunikacyjnym" i zarazem złotym środkiem między wysokim poziomem przekazu dla wąskiego audytorium a popularnym stylem $\mathrm{z}$ uproszczoną treścią dla ogółu profanów. 
Aktywny i efektywny udział (pierwsze z drugim nie zawsze idzie w parze) w debacie publicznej we współczesnych państwach demokratycznych wymaga asertywnej postawy zarówno wobec adwersarzy, jak i narzuconych reguł poprawności politycznej. W dobie dominacji mediów elektronicznych podejmowane czynności dostosowawcze mające sprostać wymogom intelektualnym i preferencjom estetycznym określonego audytorium stawiają w nowym świetle sposób odczytania jednej z podstawowych reguł dyskusji rzeczowej: suaviter in modo, fortiter in re. W takich okolicznościach „zewnętrznych” proces estetyzacji formy i treści argumentacji filozoficznej staje się niezbędnym wymogiem nie tyle logicznym, co prakseologicznym danego aktu komunikacji prowadzonego przez danego filozofa polityki.

Artykuł jest pisemną rozszerzoną wersją referatu zatytułowanego Czy filozofia polityki przeobrazi się w estetykę polityczną?, wygłoszonego 16 września 2015 r. w Poznaniu na X Polskim Zjeździe Filozoficznym w sekcji „Filozofia Społeczeństwa i Polityki”.

\section{Literatura}

Abramowitz, A.I. (2010). The Disappearing Centre: Engaged Citizens, Polarization, and American Democracy. New Haven: Yale University Press.

Acton, J.E.E., lord (1995). Historia wolności, przeł. A. Branny, A. Gowin, P. Śpiewak. Kraków: Wydawnictwo Znak, Ośrodek Myśli Politycznej.

Brożek. A. (2012). Teoria imperatywów i jej zastosowania. Kraków: Copernicus Center Press.

Bull, H. (1985). The Anarchical Society: A Study of Order in World Politics. London: Macmillan.

Charlton, B.G. (2011). Thought Prison: The Fundamental Nature of Political Correctness. Buckingham: University of Buckingham Press.

Dahl, R.A. (1971). Polyarchy: Participation and Opposition. New Haven: Yale University Press.

Dąmbska, I. (1975). „O funkcjach semiotycznych milczenia”. W: I. Dąmbska. Znaki i myśli. Wybór pism z semiotyki, teorii nauki i historii filozofii. Warszawa-Poznań-Toruń: PWN.

Dziemidok, B. (2002). „Deestetyzacja sztuki i estetyzacja życia codziennego. Kwestia zaspokajania podstawowych potrzeb estetycznych w kulturze postmodernistycznej”. W: B. Dziemidok. Główne kontrowersje estetyki wspótczesnej. Warszawa: Wydawnictwo Naukowe PWN.

Eco, U. (1999). „Nowe średniowiecze”. W: U. Eco. Semiologia życia codziennego, przeł. P. Salwa. Warszawa: Czytelnik. 
Evans, M.S. (2016). Seeking Good Debate: Religion, Science, and Conflict in American Public Life. Oakland, CA: University of California Press.

Fiorina, M.P., Abrams, S., Pope, J.C. (2005). Culture War. New York: Longman.

Giddens, A. (2001). Nowoczesność i tożsamość. „Ja” i społeczeństwo w epoce późnej nowoczesności, przeł. A. Szulżycka. Warszawa: Wydawnictwo Naukowe PWN.

Habermas, J. (2007). Strukturalne przeobrażenia sfery publicznej, przeł. W. Lipnik, M. Łukasiewicz. Warszawa: Wydawnictwo Naukowe PWN.

Hayek, F.A. von (2006). Konstytucja wolności, przeł. J. Stawiński. Warszawa: Wydawnictwo Naukowe PWN.

Hughes, G. (2011). Political Correctness: A History of Semantics and Culture. Oxford: Wiley-Blackwell.

Kampka, A. (2014). Debata publiczna: zmiany społecznych norm komunikacji. Warszawa: Oficyna Naukowa.

Keen, A. (2007). Kult amatora: jak internet niszczy kulture, przeł. M. Bernatowicz, K. Topolska-Ghariani. Warszawa: WAiP.

Locke, J. (1992). Dwa traktaty o rządzie, przeł. Z. Rau. Warszawa: PWN.

Mill, J.S. (1959). O wolności. W: J.S. Mill. Utylitaryzm; O wolności. Warszawa: PWN.

Ortega y Gasset, J. (1982). Bunt mas, i inne pisma socjologiczne, przeł. P. Niklewicz, H. Woźniakowski. Warszawa: PWN.

Popper, K.R., Condry, J. (1996). Telewizja - zagrożenie dla demokracji, przeł. M. Król. Warszawa: Wydawnictwo Sic!

Toeplitz, K.T. (2006). „Media drukowane: wzlot i upadek opinii publicznej”. W: P. Żuk (red.). Media i władza: demokracja, wolność przekazu i publiczna debata $w$ warunkach globalizacji mediów. Warszawa: Wydawnictwo Naukowe „Scholar”.

Zaller, J. (1992). The Nature and Origin of Mass Opinion. New York: Cambridge University Press.

\section{Streszczenie}

Współczesna debata publiczna w coraz mniejszym stopniu dotyka najważniejszych zagadnień dla tradycyjnej filozofii polityki, a coraz bardziej koncentruje się na samej formie wypowiedzi. Poprawność polityczna ogranicza poważne i istotne społeczne dyskusje oraz powoduje, że niektóre problemy filozoficzne stają się „nietykalne”. Wiele poruszanych publicznie kwestii zaczyna podlegać ocenie w kategoriach estetycznych. Celem artykułu jest przedstawienie współczesnego kontekstu wyznaczającego zewnętrzne warunki uprawiania filozofii politycznej i ukazanie w zarysie czynników wpływających na ramy treściowe i formalne takiej debaty.

Słowa kluczowe: filozofia polityki, debata publiczna, kategorie estetyczne, media elektroniczne 